\title{
Primary school teachers' perceptions of out of school learning within science education
}

\author{
Ann-Catherine Henriksson \\ Åbo Akademi University, Turku, Finland,
}

\begin{abstract}
This article examines what key aspects primary teachers highlight when they describe their use of out of school learning in the science subjects. The empirical study is made in the form of a semi-structured interview with primary teachers $(\mathrm{N}=15)$. Compared to earlier research in the area the results highlight the importance of clear learning aims for the outdoor sequence. The results show that teachers view outdoor education as an opportunity to study nature "for real", which, according to teachers, increases the interest of the children. As aspects that obstruct outdoor teaching, teachers mainly describe different organizational-economic aspects. In their description of the learning content in the outdoor education, teachers mainly talk about the students' interest (affective motivations) and the concrete activity or act (process-oriented motivations). The scientific subject knowledge is limited in the teachers' descriptions.
\end{abstract}

Keywords: primary school, teachers' perceptions, out of school learning, science education

Contact: ann-catherine.henriksson@abo.fi

DOI: https:// doi.org/ 10.31129/LUMAT.6.2.313

\section{Introduction and background}

In the Nordic countries there is a long tradition of outdoor education (Rea \& Waite, 2009). The use of various outdoor environments as learning environments is also recommended in the national curriculum in Finland (Finnish National Board of Education, FNBE, 2014). In Finland, Environmental studies is an integrated subject group composed of biology, geography, chemistry, physics, and health education in the grades one to six (FNBE, 2014). The learning aims for the environmental studies in grades 1- 6 are divided into three groups: 1) aims concerning values and attitudes and the meaning and the signification of the subject, 2) aims concerning scientific skills and 3) aims concerning scientific content knowledge and understanding. (FNBE, 2014). The ability to participate, influence and contribute to a sustainable future is one of the overall aims in the curriculum. (FNBE, 2014). Furthermore, in the curriculum text, the pupil's "personal relationship with nature" (p. 24) and that the pupil develops an environmental awareness are mentioned. Based on the national 
curriculum there are local curricula for each municipality in Finland. Primary teachers in primary schools in Finland usually teach most of the school subjects and have great autonomy to choose different kinds of working methods. In addition to choosing whether they use different outdoor environments as learning environments while teaching a science topic, teachers also choose different goals for their teaching in the outdoor environment and various activities in this environment.

The purpose of this study is, in light of previous research, to investigate what key aspects primary teachers highlight when they describe their use of out of school learning in the science subjects. The research questions were:

I. What key aspects do primary teachers highlight when they describe their use of out of school learning?

II. Based on the teachers' perceptions, what possible implications are there for school leadership, teacher education and in-service education?

\section{Out of school learning}

In previous research, different definitions of the concepts outdoor education and out of school learning can be found. While some researchers focus on teaching carried out in museums and various science centers (see e.g. DeWitt \& Osborne, 2007) or via contacts with experts within business or e.g. agriculture, other researchers focus on teaching that takes place in nature. Rickinson et.al. (2004) groups learning outdoors in the following overall forms: a) field work and study trips, b) adventure education and c) activities on the schoolyard and in the nearby community. Remmen and Frøyland (2017) prefer to use the term extended classroom. The term supports the thought of Harlen (2007) and Lederman, Lederman and Bell (2004) that outdoor teaching is not entertaining activities outside the school but something that is directly linked to the curriculum and aims to expand the student's understanding of the subject matter. The use of out of school learning is supported by research. According to Harlen (2007) outdoor education benefits student's learning and development, both socially, personally and at a knowledgelevel. Research shows that when teaching often is placed outdoors in an environment known to the pupil, like the schoolyard, it may have a positive effect on the student's scientific subject knowledge, attitudes and ecological awareness (see e.g. Carrier-Martin, 2003, Liefländer, Fröhlich, Bogner \& Schultz, 2013, Manni, 2015, Slade, Lowery \& Bland, 2013). Rios and Brewer (2014) also highlight the importance of creative schoolyard planning in terms of creating an 
environment that encourages children's investigations. Several studies (e.g. Bingaman \&Bradley-Eitel, 2010) show that education in the schoolyard affects pupils' science content knowledge as problem solving skills in a positive way. The positive effects of outdoor teaching can be both short-term and long-term (Rickinson et.al., 2004). Learning in an outdoor environment is holistic, and the student often utilizes several different senses associated with learning (J ordet, 2007).

Research shows that children who have positive experiences of nature are also more interested in e.g. environmental issues (Uitto, J uuti, Lavonen \& Meisalo, 2006). In the European Union (EU) recommendations for competences for lifelong learning, scientific literacy is one of the eight key competences (EU, 2006). In the current curriculum in Finland (FNBE, 2014) education for sustainable life and active and responsible citizenship has an important role on a general level and in specific subjects. Positive attitudes towards environment and responsibility are fostered by positive experiences in nature and a pupil's perception of competence to act (Chawla \& Flanders Cushing, 2007). Elementary grades are an opportune time to develop environmental attitudes (Rios \& Brewer, 2014). Here teachers and parents are important as role models. Like science in general, environmental education can be divided into three dimensions: learning in or of the environment, learning about the environment and learning and action for the environment (Palmer, 1998). Palmer's tree model is further developed by Reunamo and Suomela (2013). At the center of the model are the goals of environmental knowledge, skills and attitudes. In the developed model, the authors further highlight the importance of the student's own experiences as well as the student's sense of participation, community and understanding.

Rickinson et.al. (2004) recommends that the outdoor trips should be carefully planned and formed into wholes. The trip must be prepared and afterwards processed together with the pupils, the trip and the learning should be linked to the objectives of the curriculum and assessed according to this, and the activities during the outdoor stay must be linked to the objectives. Almost identical recommendations are given by Rennie (2007) who additionally stresses the importance of teachers receiving sufficient planning time for outdoor activities from the school administration and that organizational barriers, for example, insufficient timetables, are minimized. Research (e.g. Faria \& Chagas, 2013) shows that teachers rarely provide students with preassignments and/ or post-duties in connection with outdoor teaching. On the basis of previous research findings, Remmen and Frøyland (2017) have compiled six different 
criteria for an outdoor teaching structure according to the model "the extended classroom" (trans. and processed by the author).

1. A chosen theme that can be investigated from many different perspectives.

2. An assignment that the students will solve.

3. Formulated learning aims (knowledge, methods, aim and form) which scaffold the pupils in solving the assignment.

4. What can the students do in this learning environment that they cannot do in the classroom?

5. Choose activities (pre-assignments, outdoor activities, post-assignments) where the pupils demonstrate their understanding and which increases their deep learning.

6. Formative assessment is used during the work in order to scaffold the pupils to solve the assignment and to investigate where the pupils are according to the learning aims.

There are numerous studies that highlight various challenges within out-of-school education. As limiting factors for the use of out of school education, teachers mention according to Harlen (2007) and Rickinson et.al. (2004) teachers' lack of self-efficacy, lack of time due to the crowded curriculum, new safety regulations, responsibility issues as well as economic factors such as transport costs. According to Wilhelmsson (2012), even the pupils' non-conformal attire can be a limiting factor. Nature can also be perceived as something scary by students (Rickinson et.al., 2004). For students who are not used to staying outdoors during instruction, the first few times the students are too busy to process the new impressions and the unfamiliar environment in order to be able to learn about the subject itself. This applies in particular to students who are used to lecture focused teaching in the classroom. However, with time and support, students can develop new effective study skills in outdoor education. (White, 1988). Outreach can be an objective in itself. Learning to moveand take excursions in nature and the built environment is also a learning objective in the national curriculum (FNBE, 2014). In the results of a Swedish study (Szczepanski, 2013) about primary teachers' perceptions of the meaning of the place for teaching and learning, the teachers perceived that teaching and learning outdoors means the following: discovering other learning environments besides the classroom, using large open spaces, utilizing the spatial diversity of outdoor environments, promoting interaction between different learning environments, uniting theory with practice, 
applying a bodily, sensible learning, creating varied meetings with different phenomena, creating an outdoor platform for environmental work, and finally spending time more freely.

In order to increase the proportion of teaching outside the school's building, teachers according to Rios and Brewer (2014), need further in-service education on outdoor education and increased self-confidence in using different out-of-school learning opportunities. In order to create an understanding of natural concepts, meaningful goals and the ability to take responsibility for one's own actions are necessary. Natural science is also associated with ethics, morals and values (Roth, 2006).

Evoking pupil curiosity and interest for science and for phenomena in the environment is an important aim in science education overall and in out of school learning (DeWitt \&Osborne, 2007). "The aim of the teaching is to awaken and deepen students' interest in the different subjects within environmental education."...'With the help of problem solving and investigative tasks, the interest in phenomena in the environment is deepened" (FNBE, 2014, p. 240). However, Andersson (2008) is critical of placing pupil interest as the most important aim for science education. Pupil interest, attitudes and process skills are important, but according to Andersson (2008) and Tobin (2006) teachers have to raise the ambitions higher and successively absorbe and use science concepts to reach systematics in the curiosity. Students do not understand more natural science just because they are socially or physically active. It depends on the quality and depth of student activity and conversation. (Remmen \& Frøyland, 2017). In a constructivist approach to learning pupil motivation and consciousness of the learning aims have important roles (Gärdenfors, 2010; OECD; 2007; Sjøberg, 2000). The pupils' motivation for learning is affected by their areas of interest and their curiosity. These aspects are favored when pupils perceive challenge and work with current and actual problems from the pupil's point of view (Harlen, 2007; 2010).

\section{Teachers' perceptions}

Clark and Peterson (1986) divide the teaching process into two different domains: a) the teacher's (invisible) thought processes and $b$ ) the teacher's actions and observable effects of action. The teacher's thoughts affect the action, but the action in turn reflects the teacher's new thinking processes. (Figure 1.) 


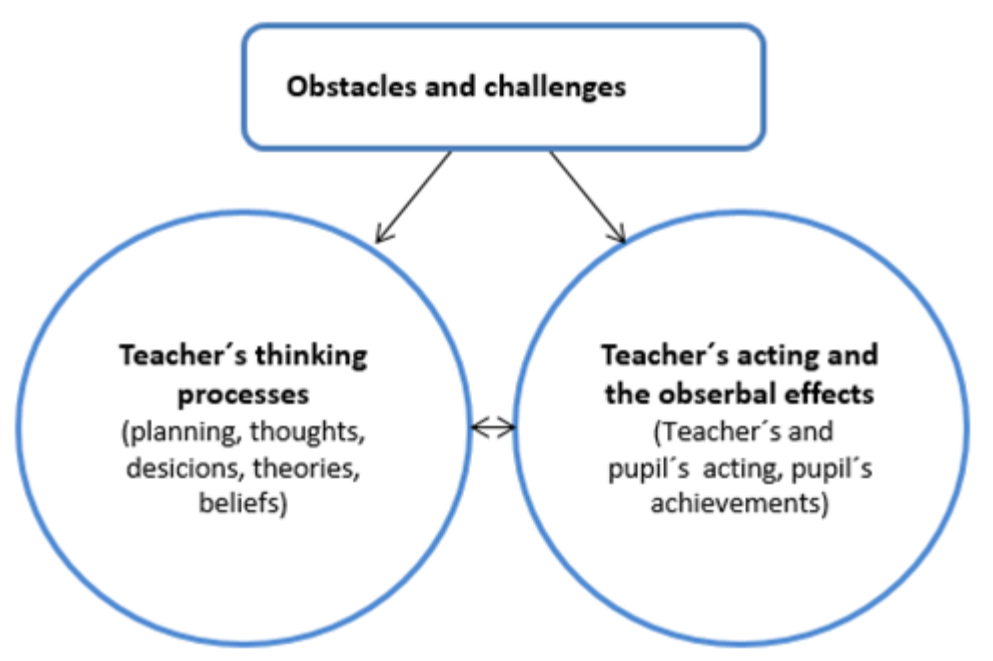

Figure 1. Model about the teacher's thoughts and actions (processed from Clark \& Peterson, 1986, p. 257)

The teacher's thought processes can be divided into the teacher's planning categories (both before and after teaching), the teacher's interactive thoughts and decisions, as well as the theories and beliefs of the teacher. Different obstacles and challenges affect both the teacher's thought processes and the teacher's actions. This study focuses primarily on the teacher's thought processes in relation to science teaching. The teacher's aims for the teaching, classroom practices and activities are affected by the teacher's different values and perceptions of learning (Wilhelmsson, 2012) and teachers' beliefs and attitudes (Haney, Lumpe, Czerniak \&Egan, 2002). Research also shows that teacher attitudes toward phenomena in nature and to sustainable development can affect students' attitudes and choices in both positive and negative directions (Carrier-Martin, 2003). In their research about primary school teachers' attitudes to science, van Aalderen-Smeets and Walma van der Molen (2015) describe how the teacher's dependency on context factors (e.g. dependency on materials and sufficient planning time) affect the teacher's perceived control. Teachers with high self-efficacy beliefs regarding science and science teaching feel less dependent on context factors. The teacher's perceived control affects the teacher's behavioral intent and behavior.

Marton (1997) warns about trying to compare different teaching methods and activities with each other. What is more important, according to Marton, is to investigate what the student is supposed to learn from the method, i.e. what competences one wants to achieve. Instead of asking the question, 'What does work?', 
the teacher should ask 'For what does it work?'. Hattie (2012) points out that for teachers it is also important to evaluate the effect of the methods used.

The teacher's educational actions are at best targeted. The goals for which the teacher's actions are directed can be partly the goals of the curriculum and the goals the teacher personally sets for his teaching. In order for the thinking to be targeted, the teacher should first know the goals, accept them and embrace the thinking in the goals. The curriculum goals and the teacher's thoughts and actions then form a whole (Kansanen, 2004). According to Clark and Peterson (1986), however, teachers focus their planning primarily on the substance and the students' activities. The national curriculum (FNBE, 2014) also emphasizes the importance of the student being involved in the formulation of learning objectives. Remmen and Frøyland (2007) also emphasize that the aims of the teacher and different experts do not always correspond to the pupil's aims for the out-of-school education. Research shows that the same basic aspects that benefit student learning also benefit the teacher and teacher learning and teaching. Aspects that emerge are targeting, time for reflection, collaborative learning, cooperation, interest and motivation (see e.g. Harlen \& Qualter, 2014; Shulman \& Shulman, 2004).

\section{$4 \quad$ Methodology and analysis}

This article examines what key aspects primary teachers highlight when they describe their use of out of school learning in the science subjects. Teachers' qualitatively different perceptions of phenomena and the variation in these perceptions are investigated. The epistemological approach to the study is phenomenographical. The ground unit in the research is a way of perceiving something. The object of the research is the variation in the ways of perceiving the phenomena. The empirical study is made in the form of a semi-structured interview with primary teachers $(\mathrm{N}=15)$. The teachers in this study are formally competent primary teachers working with children in grades 3 - 6 in various Swedish speaking schools $(\mathrm{N}=15)$ along the coastal boarder of Finland. The teachers' backgrounds regarding teaching career and teacher training varied as well as the size and the urban-rural surroundings of the school. Three of the teachers were male. The interviews were recorded on two dictaphones and took place after the pupils in the class had left school for the day. The verbal data was transcribed by the author in order to conduct a thematic analysis. A pseudonym was used for each of the teachers. The data corpus of teachers' experiences was then analyzed 
thematically on three levels:

1. a data set consisting of all instances where the teachers are referring to out of school learning

2. data extracts on a personal level are analyzed and thematically coded and

3. qualitatively different themes on a general level are coded.

Table 1 illustrates and exemplifies the procedures in the analyze process. To illustrate the meaning of the themes, quotes are used. In connection with the quotation, pseudonyms are used. The outcome of the analysis is discussed against the background of previous research and guidelines and objectives in the curriculum in section 6.

Table 1. Classification and coding during the analyze process - an example.

\begin{tabular}{|c|c|c|c|c|}
\hline $\begin{array}{l}\text { Data } \\
\text { corpus }\end{array}$ & $\mathbf{I}$ & II & III & III \\
\hline \multirow[t]{8}{*}{$\begin{array}{l}\text { Teachers' } \\
\text { answers } \\
\text { during the } \\
\text { interviews }\end{array}$} & $\begin{array}{l}\text { All instances } \\
\text { referring to } \\
\text { out of school } \\
\text { learning }\end{array}$ & ... and watch more concrete things & $\begin{array}{l}\text { Potential } \\
\text { themes } \\
\text { Concrete work }\end{array}$ & $\begin{array}{l}\text { Qualitatively } \\
\text { different } \\
\text { themes on a } \\
\text { general level }\end{array}$ \\
\hline & & ... for it to be still more concrete & & \\
\hline & & $\ldots$ in order to get more change & Variation & \\
\hline & & ... in this way to be able to get variation & & \\
\hline & & $\begin{array}{l}\text {... to raise the interest for the school } \\
\text { subject }\end{array}$ & Pupil's interest & $\begin{array}{l}\text { Motivating } \\
\text { aspects }\end{array}$ \\
\hline & & $\begin{array}{l}\text {... if you can't be in your room you have } \\
\text { to go out. }\end{array}$ & $\begin{array}{l}\text { Small and/or } \\
\text { unsuitable } \\
\text { classrooms }\end{array}$ & \\
\hline & & $\begin{array}{l}\text { It is easier for me. I can work with things } \\
\text { like forces and water. }\end{array}$ & & \\
\hline & & $\begin{array}{l}\text { When I think about outdoor teaching - } \\
\text { one reason for me is that I am so } \\
\text { interested in being outdoors myself }\end{array}$ & $\begin{array}{l}\text { Teacher's own } \\
\text { interest }\end{array}$ & \\
\hline
\end{tabular}


An inductive approach always incorporates some pre-understanding. (Bjereld, Demker \& Hinnfors, 2009; Dalen, 2007; Larsson, 2005). However, the research should be valid so that it is empirically anchored and coherent. The empirical anchoring is, according to Larsson (2005), that there must be a correspondence between reality and interpretation. Within the phenomenological approach, the idea is that all analysis and interpretation should be rooted in the interviews. The various descriptive categories are therefore illustrated and highlighted by using direct quotes from the interviews as examples. There must be an internal logic or coherence throughout the work. The research purpose steers the choice of theory, research effort, methodology and analysis. Every interpretation in the analysis means, according to Larsson (2005, p. 24) "a tension between the demands for consistency and empirical anchoring". To obtain internal logic throughout the work the theoretical background, the results and the discussion are structured based on the research questions. Synonyms for the research reliability could be precision and accuracy. Dalen (2007) emphasizes the importance of being clear and just about the various aspects of the research process. In the account of how the empirical collection has been carried out, written and analyzed a careful description is important. During the interviews, it is important to keep in mind that the interviewer neither in the matter or in voice mode, gestures, etc. affect the interviewee in any way. The aim of this study is not to provide all possible perceptions that primary teachers generally have or will have. The goal is to get the variety of perceptions that can be studied regarding this group of qualified primary teachers. This aim is consistent with what Maxwell (2005) calls for internal generalizability.

\section{$5 \quad$ Findings}

All teachers in the study stated that at least sometimes during the academic year they go out with the students in connection with science teaching and especially in the field of biology. In the following, the teachers' perceptions are presented under the main themes that have emerged during the analysis.

\subsection{Out of school learning in the form of out-door-activities}

Teachers describe how they, together with the students, visit different places in the school's immediate environment. Visits are made e.g. to a nearby forest, lake, river or to the shore. Visits are made on foot or by bicycle, and it is often a visit that spans one 
or two lessons. Even longer-term trips are made in the form of out-of-school day (where students stay overnight in tents) or as a camp-school for a whole school week. During the outing the pupils often study plants. Pupils observe and examine plants, for example, using a microscope. During the field excursions, pupils can also study different birds. Even though Anna works in a city school, she states that she largely utilizes the schoolyard as a place where students can become acquainted with different plants and cultivation. Even Johanna and Tommy make use of their schoolyards and their possibilities in outdoor teaching. Anna also describes how she, together with the students, have created a schoolyard where students grow different grains which are then examined and used for baking. While biology-related issues are common, teachers describe fewer issues related to the knowledge content in geography and physics. Teachers emphasize the difference between biology and geography when it comes to opportunities for out of school learning, mentioning that they rarely or never go out during the geography sections. As a reason, they mention the time of year and the nature of the content.

"Then in biology you try to go out into nature... In the autumn ... we have a lake, a swamp actually, which has grown again. So that's good of course. But in geography, if you think about the fifth and sixth year course, they read about Europe and the rest of the world, then it's not just getting out of the door and benefiting from it. "(Olle)

Regarding different chemistry-related content topics, teachers mainly mention the theme of water. Teachers also describe how they work with subjects integrated during the outing. The subjects mentioned by teachers are sport, craft and mother tongue.

\subsection{Collaboration between classroom teachers and external professionals}

Teachers see cooperation with outside experts as something positive. The trips can at best enhance both the students' and teachers' learning.

"And it was like an injection of ideas for me too. I got so many new ideas from her this teacher who is always in nature with the kids and does stuff with them and it was noticed that the kids also thought it was fun and looked forward to these times. It would be great to be able to bring in such outside experts and do fun things and go on small trips. "(Siv)

Students can either visit a natural school, or a natural school can visit the school to arrange a teaching opportunity. The Forestry Center also offers popular education 
opportunities for schools. In connection with time-long school trips, teachers and the students have visited a national science center that can offer lesson packages and exhibitions. Anna describes how she has visited a gardening company and a mill with her students in connection with the class culture project. School visits are also made to different services in the community. Teachers describe that they have visited, for example, power plants and water treatment plants.

\subsection{Aspects that motivate out of school learning}

As an advantage of outdoor education, teachers mention the possibility of studying nature in concrete terms or "on real", which increases the interest of the children. The outdoor environment offers many opportunities for concrete investigative and practical work. The outdoor environment also offers students variation in the school day. Teachers also describe outdoor teaching as a good option since the school's facilities are too small or unsuitable for teaching in e.g. physics and chemistry.

"It will be easier for me. I can work with both power and water and different things in the water and filtering and measurements and that kind of practical things. I like to do that outdoors." (Diana)

A strongly motivating aspect is the teachers' own interest in being out with the students. The teachers' own interest in being outdoors drives them to bring the students out of the classroom. Pupils with different special interests and knowledge can be given the opportunity to show them during their stay outdoors. Anna describes how she adapts her students' pre-knowledge and interest areas and uses it as a starting point for the outdoor education.

"... that I work very often outdoors and I work a lot based on what the children can and ... just that ... we spin on then from that and maybe take it into several different subjects or make a product." (Anna)

\subsection{Purpose and learning goals}

The main purpose of out of school education according to teachers is to increase or to maintain the pupils' interest in science and nature.

"Well, in grade three and four, I just like to evoke interest and like to take them [the pupils] out in nature and sort of look at how things really are and so ... that they are really going to be interested and it is very useful then because children love both animals and nature."(Anna) 
The only learning goal to be mentioned by a teacher in the study is that pupils by visiting different social services gain an idea of how society works. Teachers also express concern that learning goals are not met if the students work outdoors instead of in the classroom. Erik describes how he worries that the biology "flows out" if students study the topics outside the classroom.

\begin{abstract}
"So what is it called ... it requires planning ... and then that not everyone is so focused. There may be some [pupils] who, as you know, understand the data, or everyone can understand ... but to do what you do not like, that the biology just flows out ...that is what you are afraid of." (Erik)
\end{abstract}

\title{
5.5 Challenges connected to out of school learning
}

A challenge according to teachers is that the students' interest in science and being outdoors decreases as age increases. Nature, and especially the forest, can also be experienced by some students as scary. Diana describes how students need to work on staying in and moving in nature before they can focus on the subject matter. For students with different mobility disabilities, outdoor education can cause practical problems.
"... ..but there I have to think that I'm doing such teaching so that the pupil can join. Having a wheelchair in the woods is not optimal ... so maybe it's better to take parts of nature in class instead of going out when everyone can't come along "(Pia)

Olle raises a security perspective and believes that it is not safe for the teacher to take the students out if you can't rely on them to follow the teacher's instructions. According to Tommy, there are major differences between the groups in terms of interest in outdoor education. He tells us that he has had classes that he has completely avoided going out with because of the pupils' behavior.

For the teacher, outdoor education can mean more planning. As aspects that complicates outdoor teaching, teachers mainly mention different organizationaleconomic aspects. Tight timetables and, for example, taxi riders can make it difficult to carry out different trips. The school day is divided by the teacher's lessons in other classes, other teachers' lessons in the class or lunch schedules. Pupils who come to school by taxi or public transport have difficulty taking a bike that would be needed for e.g. a field trip. Arranging trips that require transport with e.g. buses incur additional costs for the school. The tough economic times in the municipalities have 
meant that schools have had to cut back on these expenses. Anna believes that the lack of funds limits the use of different transports.

"You do what is possible. No, I have quite a few lessons in my own class so it's probably good. But just this I want, I have decided that I always have two lessons after each other in science. Just because you can go out and do something. That there is no other teacher who is waiting for you." (J ohanna)

Seasonal changes can also cause problems for teaching. Teachers often choose biology-related themes for outdoor activities. In schools in the northern part of Finland, spring is, according to teachers, often so late that few plants can be studied then.

\subsection{Visions connected to out of school learning}

Teachers wish to work with more concrete activities and increase the use of outdoor education. In order for this to be possible, teachers want flexible group divisions and/ or smaller student groups. Several teachers participating together in outdoor education is viewed by teachers being positive. They ask for different models with companion teachers in the class. Overall, teachers experience a need for more adults in school.

\footnotetext{
"Then there might be several adults in school. That you could have more flexible groups and it would be easier to do some things with the students, to go away with students or to watch a few things with fewer students. I think it could bring benefits." (Berit)
}

\section{Discussion and implications}

The teachers use outdoor education in their teaching. The environment (nature) is, in particular, actively used by teachers. Based on the positive research findings regarding outdoor education's influence on the student's science content knowledge, problem solving skills as attitudes towards environmental issues, this is positive. In the teachers' descriptions it can be seen that outdoor education mainly takes place with a focus on biology and less in the content areas of geography, physics and chemistry. Of the categories for outdoor education presented by Rickinson et.al. (2004), teachers mainly describe different activities nearby the school and in the community as well as, to some extent, different study visits while the area of adventure education is not highlighted. 
Regarding aspects that obstruct outdoor teaching, teachers mainly describe different organizational-economic aspects like timetables, adult resources and transports. Some teachers would like to be out more with the students while teaching. This revolves around Rennie's (2007) thoughts that teachers from the school management need to have adequate planning time for outdoor education and that the effects of the organizational barriers, for example, tight timetables are minimized. Challenges are a fact (Clark \& Peterson, 1986) but how much teachers allow themselves to be influenced by these challenges depends on the teacher's attitudes and self-efficacy (van Aalden-Smeets \&Walma van der Molden, 2015).

The results show that teachers see outdoor education as an opportunity to study the nature concrete or "on real", which, according to teachers, increases the interest of the children. Learning outside the school can also be a good option as the school's spaces are too small or unfit for science teaching. A comparison between the results of this study and the Swedish survey (Szczepanski, 2013) shows that there are many similarities between teachers' perceptions. Teachers in both studies emphasize the opportunity for pupils to work practically and have varied meetings with different phenomena. The outdoor environment also offers larger areas compared to the classroom environment. The Swedish teachers feel they can spend time outdoors more freely, while the Finnish teachers highlighted the need for flexibility when it comes to timetables. In the Finnish teachers' perceptions, the environmental work is not highlighted in connection with out of school learning. However, in the new national curriculum the pupil's development of an environmental awareness is stressed (FNBE, 2014).

In their description of the learning content in the outdoor education environment, teachers mainly talk about the student's (and the teacher's) interest (affective motivations) and the concrete activity or act (process-oriented motivations). These are important aspects in order to increase the pupils' motivation for science learning. The scientific subject knowledge, in the form of increased understanding of central concepts, phenomena and relations, with the exception of the mentioning of different plant species, is limited in the teachers' descriptions. In view of the new curriculum of environmental education and its subdivisions (FNBE, 2014), teachers should gain more knowledge about the use of outdoor education in the areas of physics chemistry, health education and geography. The linking between learning aims, theory and practice is not highlighted in the teachers' perceptions. For the pupil's motivation, it is important that he experiences a sense of participation, community and 
understanding (see e.g. DeWitt \& Osborne, 2007, Reunamo \& Suomela, 2013). The pupil's ownership of his knowledge and active participation in the goal setting work is also emphasized in the curriculum (FNBE, 2014). Clear learning goals, pre- and postassignments and a formative assessment aimed at supporting pupil learning are also criteria for a good outdoor education according to Remmen and Frøyland (2017).

As with other teaching methods and environments, teachers in the study indicate that students need to practice to stay and move in nature before they can begin to immerse themselves in the subject matter. This is also emphasized by White (1988). According to Anna, children are sometimes afraid of going out into nature, as is also evident from the research compilation of Rickinson et al. (2004). The schoolyard as a learning environment is highlighted by teachers, but only to a very small extent. Not having to travel long distances for outing facilitates simplifies the teacher's planning in several ways. The proximity to school can make the teacher to feel more safe to supervise a group of students outdoors. Outdoor visits can be done more often and thus become a recurring part of the teaching, which is also recommended by, for example, Carrier-Martin (2003). The fact that teaching is conducted in the vicinity of the school also means that transport costs are avoided. In view of the positive results (according to science content knowledge, pupil's attitude, ecological awareness and problem solving skills) from outdoor learning on the schoolyard (e.g. Bingaman, Bradley-Eitel, 2010) an increased use of school grounds as a learning environment is recommended.

The study is about the teachers' perceptions regarding outdoor learning and what they highlight. It is important to hear what the teachers say, but it is also important to reflect on what aspects these teachers do not mention. As stated, teachers talk very little about the learning aims for teaching in out-of-school settings. Furthermore, they do not describe how and if they do prepare the pupils for the tasks with preassignments or if they follow up the tasks with post-assignments. Not one of the teachers mentions the children's or the teacher's use of digital tools during the outdoor education.

The teachers' attitudes towards outdoor education are important. The teachers' lack of self-confidence in outdoor education is according to e.g. Harlen (2007) and Rickinson et.al. (2004) an aspect that decreases their use of outdoor environments for learning. Teachers need support to increase their confidence. As Rios and Brewer (2014) suggest this actualizes the importance of teacher education and in-service education regarding the teaching of science content in an outdoor setting. Teachers 
can be educated to see the possibilities of outdoor education from a broader perspective and to scaffold the pupils into deeper learning.

\section{References}

Van Aalderen-Smeets, S.I \& Walma van der Molen, J.H. (2015). Improving primary teachers' attitudes toward science by attitude-focused professional development. J ournal of Research in Science Teaching, 52(5), 710-734. doi:10.1002/tea.21218.

Andersson, B. (2008). Grundskolans naturvetenskap - helhetssyn, innehåll och progression. Lund: Studentlitteratur.

Bingaman, D. \& Bradley-Eitel, K. (2010). Boulder Creek study. Science and Children, 47(6), 5256.

Bjereld, U., Demker, M.\& Hinnfors, J. (2009). Varför vetenskap? Lund: Studentlitteratur.

Carrier-Martin, S. (2003). The influence of outdoor school-yard experiences of students' environmental knowledge, attitudes, behaviors and comfort levels. J ournal of Elementary Science Education, 15(2), 51-63.

Chawla, L. \&Flanders Cushing, D. (2007) Education for strategic environmental behavior. Environmental Education Research, 13(4), 437-452. doi:10.1080/ 13504620701581539

Clark, C.M. \& Peterson, P.L. (1986). Teachers' Thought Processes. In M. C. Wittrock (Eds.), Third Handbook of Research on Thinking (pp. 255-296). New York: Mc Millan.

Dalen, M. (2007). Intervju som metod. Malmö: Gleerups.

DeWitt, J \& \& Osborne, J . (2007) Supporting Teachers on Science-focused School Trips: Towards an integrated framework of theory and practice, International J ournal of Science Education, 29(6), 685-710, doi:10.1080/09500690600802254

European Union (2006). European Union's Recommendation on Key Competences for Lifelong Learning. Retrieved from http:// eur-lex.europa.eu/ legalcontent/ EN/TXT/ ?uri=celex:32006H0962

Faria, C. \& Chagas, I. (2013). Investigating school-guided visits to an aquarium: What roles for science teachers? International J ournal of Science Education, 29(6), 685- 710. doi:10.1080/09500693.2012.674652

Finnish National Board of Education, FNBE (2014). National core curriculum for basic education. Helsinki: FNBE.

Gärdenfors, P. (2010). Lusten att förstå. Om lärande på människans villkor. Stockholm: Natur och kultur.

Haney, J .J ., Lumpe, A.T., Czerniak, C.M.,\&Egan, V. (2002). From beliefs to actions: The beliefs and actions of teachers implementing change. J ournal of Science Teacher Education, 13, 171-187. doi:10.1023/ A:1016565016116.

Harlen, W. (2007). Assessment of learning. London: Sage.

Harlen, W. (red.) (2010). Principles and big ideas of science education. Association for Science Education.

Harlen, W. \& Qualter, A. (2014). The Teaching of Science in Primary Schools. London: Routledge.

Hattie, J . (2012). Synligt lärande för lärare. Stockholm: Natur \& Kultur.

J ordet, A, (2007). "Nærmiljøet som klasserum"- En undersøkelse om uteskolens didaktikk i et danningsteoretisk og erfaringspedagogisk perspektiv (Doctoral dissertation). University of Oslo.

Kansanen, P. (2004). Opetuksen käsitemaailma. J uva: PS-kustannus. 
Larsson, S. (2005). Om kvalitet i kvalitativa studier. Nordisk Pedagogik, 25(1), 16-35.

Lederman, N.G., Lederman, J .S. \& Bell, R. L. (2004). Constructing Science in Elementary Classrooms. Boston: Pearson Education Inc.

Liefländer, A.K., Fröhlich, G., Bogner, F.X. \& Schultz, P.W. (2013). Promoting connectedness with nature through environmental education. Environmental Education Research, 19(3), 370384. doi:10.1080/ 13504622.2012.697545

Manni, A. (2015). Känsla, förståelse och värdering Elevers meningsskapandei skolaktiviteter om miljö- och hållbarhetsfrågor (Doctoral dissertation). Umeå University, Institution for didactics in science and mathematics.

Marton, F. (1997). Mot en medvetandes pedagogik. In M. Uljens (Eds.), Didaktik (pp. 98-119). Lund: Studentlitteratur.

Maxwell, J .A. (2005). Qualitative Research Design: An Interactive Approach. Thousand Oaks, CA: Sage.

OECD (2007). Understanding the Brain: The Birth of a Learning Science. OECD, Paris. Retrieved from http:/ / www.oecd.org/ site/ educeri21st/ 40554190.pdf

Palmer, J . A. (1998). Environmental education in the 21 st century: theory, practice, progress and promise. London: Routledge.

Rea, T. \& Waite, S. (2009). International perspectives on outdoor and experimental learning. Education 3 - 13, 37(1), 1-4. doi:10.1080/03004270802291699

Remmen, K.B. \& Frøyland, M. (2017). “Utvidet klasserom”- Et verktøy for å designe uteundervisning i naturfag. NorDiNa, 13(2), 218-229. doi:10.5617/ nordina.2957

Rennie, L.J . (2007). Learning science outside of school. In S.K. Abell \& N.G. Lederman (Eds.), Handbook of Research on Science Education (pp. 125-167). Machwah, NewJ ersey: Lawrence Erlbaum Associates.

Reunamo, J . \& Suomela, L. (2013). Education for sustainable development in early childhood education in Finland. J ournal of Teacher Education for Sustainability, 15(2), 91-102. doi:10.2478/jtes-2013-0014

Rickinson, M., Dillon, J., Teamey, K., Morris, M., Choi, M.Y., Sanders, K. \& Benefield, P. (2004). A review of research on outdoor learning. Slough: National Foundation for Educational Research and King's College London.

Rios, J.M. \& Brewer, J . (2014). Outdoor education and science achievement. Applied Environmental Education \& Communication, 13, 234-240. doi:10.1080/ 1533015X.2015.975084

Roth, W.M. (2006) Scientific Literacy. In K. Tobin (Eds.), Teaching and Learning Science- A Handbook, Volume 1 (pp. 69-78). London: Praeger.

Shulman, L.S. \& Shulman, J.H. (2004). How and what teachers learn: a shifting perspective. J ournal of Curriculum Studies, 36(2), 257-271. doi:10.1080/0022027032000148298

Sjøberg, S. (2000). Naturvetenskap och allmänbildning - en kritisk ämnesdidaktik. Lund: Studentlitteratur.

Slade, M.S., Lowery, C. \& Bland, K. (2013). Evaluating the impact of forest schools: A collaboration between a university and a primary school. Support for Learning, 28(2), 66-72. doi:10.1111/ 1467-9604.12020

Szczepanski, A. (2013). Platsens betydelse för lärande och undervisning: ett utomhuspedagogiskt perspektiv. NorDiNa, 9(1), 3-17. doi:10.5617/ nordina.623

Tal, T., Alon, N.L. \& Morag, O. (2014). Exemplary practices in field trips to natural environments. J ournal of Research in Science Teaching, 51(4), 430-461. doi:10.1002/ tea.21137

Tobin, K. (2006). Analyses of current trends and practices in science education. In K. Tobin (Eds.), Teaching and Learning Science- A Handbook, Volume 1 (pp. 3 - 16). London: Praeger. 
Uitto, A., J uuti, K., Lavonen, J . \& Meisalo, V. (2006). Students' interest in biology and their out-ofschool experiences. J ournal of Biological Education, 40(3), 124-129. doi: 10.1080/ 00219266.2006.9656029

White, R.T. (1988). Learning Science. Oxford: Basil Blackwell Ltd.

Wilhelmsson, B. (2012). Teachers' intentions for outdoor education: conceptualizing in different domains. Umeå Universitet. Department of Science and Mathematics Education. 